Research Article

\title{
DIFFERENT BODY MEASUREMENT AND BODY WEIGHT PREDICTION OF JAMUNA BASIN SHEEP IN BANGLADESH
}

\author{
M.A. Sun, M.A. Hossain, T. Islam, M.M. Rahman \\ M.M. Hossain and M.A. Hashem* \\ Department of Animal Science, Bangladesh Agricultural University \\ Mymensingh, Bangladesh
}

\begin{abstract}
The aim of this study was to estimate different body measurements and derive prediction equation for live weight of Jamuna basin sheep using different body measurement. A total of 520 individual records of sheep (47 males and 473 females) including all temporary at nine-month age (320), first pair permanent at 1.6 year age (161) and 2nd pair permanent at two years age (39) were collected from two Upazila of Sherpur district. Body weight (BW) was taken using a weighing scale and different measurements were taken using the tailor's tape measure and measuring stick while animals were on standing position. Data were analyzed with the help of SPSS-v-20 computer package program. Average $B W$, wither height $(\mathrm{WH})$, rump height $(\mathrm{RH})$, body length $(\mathrm{BL})$, sternum height(SH), body depth(RD), bi-costal diameter(BD), ear length(EL), rump width(RW), head width(HW), rump length( $R L)$, head length $(\mathrm{HL})$, heart girth $(\mathrm{HG})$, cannon bone circumference $(\mathrm{CC})$ and muzzle diameter(MD) were $12.28 \pm 2.75 \mathrm{~kg}, 49.42 \pm 3.78,54.04 \pm 3.88,49.38 \pm 4.57$, $28.06 \pm 3.00, \quad 53.09 \pm 4.40, \quad 15.07 \pm 2.58, \quad 8.66 \pm 3.32, \quad 15.72 \pm 2.33$, $12.87 \pm 2.20, \quad 14.30 \pm 2.29, \quad 18.23 \pm 2.30, \quad 55.02 \pm 4.71, \quad 9.22 \pm 1.01$, and $16.65 \pm 1.73 \mathrm{~cm}$, respectively. According to sex $\mathrm{BW}, \mathrm{WH}, \mathrm{RH}, \mathrm{SH}, \mathrm{RD}$ and CC were found significant $(p<0.001), H G$ and $M D$ were found significant $(p<0.01)$. Stepwise multiple regression analysis according to agein all temporary groups showed that the body weight was found the best fitted equation having the highest $R^{2}$ value $64 \% \quad(B W=-$ $15.53+0.24 \mathrm{HG}+0.13 \mathrm{WH}+0.16 \mathrm{BD}-.1 \mathrm{RW}+0.05 \mathrm{EL})$ whereas in 1.3-1.6 and 1.9-2 years age group the $R^{2}$ value for $B D$ was 56 (BW =$15.65+0.31 \mathrm{HG}+0.22 \mathrm{WH})$ and $83 \%(\mathrm{BW}=-24.51+0.21 \mathrm{RH}+0.35 \mathrm{HG}+0$. 19BL-0.78RL+1.2RW-0.87HW), respectively. $R^{2}$ value for $B D$ in male $(B W=-28.91+0.43 \mathrm{HG}+0.35 \mathrm{WH})$ and female $(\mathrm{BW}=-10.62+0.27 \mathrm{HG}+$ $0.13 \mathrm{WH}+0.06 \mathrm{BD}-0.13 \mathrm{HW}+0.07 \mathrm{BL}-0.10 \mathrm{SH}-0.10 \mathrm{RL}$ ) was 88 and $59 \%$, respectively. It is concluded that the best prediction parameter of $\mathrm{BW}$ was $H G, W H, B D, R W, E L, R H, B L$ and $H W$.
\end{abstract}

"Corresponding author: hashem_as@bau.edu.bd 
Keywords: Body weight, Body measurements, Jamuna basin sheep, Regression analysis, Sex, Age

\section{INTRODUCTION}

Live body weight plays a vital role for determining several characteristics of farm animals (Pesmen and Yardimci, 2008). Estimating the live weight using body measurements is practical, faster, easier and cheaper in the rural areas where the resources are insufficient for the breeder (Nsoso et al., 2004). This fundamental knowledge of BW estimation is often unavailable to farmers due to unavailability of scales. Hence, the farmers have to rely on questionable estimates of BW of their animals leading to inaccuracies in decision making and husbandry (Moaeen-ud-Din et al., 2006). In recent years, there have been a great number of studies on the prediction of BW from various body measurements taken at different growth periods of sheep (Cam et al., 2010). The BW information can be used in determining the value of animals and efficiency of rearing. Body measurements are important data sources in terms of reflecting breed standards (Riva et al., 2004) and are also important for providing information about morphological structure and development ability of the animals. Body measurements differ according to the factors like breed, gender, productivity, age and climatic condition. There are 3.537 million sheep (DLS,2019); of which $42 \%$ are reared in three ecological zones as Barind, Jamuna basin and Coastal areas. Most of the sheep are indigenous, with few crossbreds (Bhuiyan, 2006) and are capable of bi-annual lambing and multiple births. In Bangladesh, sheep production is reputed due to their high prolificacy, early maturity, extreme disease resistance, superior skin quality, and wide range of adaptability under adverse agro-climatic condition (Sultana et al., 2011).The most widely used methods for estimating the weight of sheep under farm condition are using a regression equation developed from other linear body measurements for breed/population of interest (Melesse et al., 2013). BW is important for assessing the condition of animal and represents a criterion of selection. The dosage of medication during health care and the required amount of feed depends on the weight of animal. Though BW is an important economic trait, it is rarely measured by rural livestock farmers due to lack of weighing scales. Small scale farmers rely on guess-estimates of the animal's BW which add to inaccuracies in animal husbandry practices (Slippers et al., 2000). Thiruvenkandan (2005) highlighted that this problem could be overcome by regressing BW on a number of body characteristics which can be measured easily. Such a method has been used by several authors for different species. The heart girth has been used to predict BW in various species of some indigenous animals like sheep of Cameroon, goats in West Africa and cattle in South Africa (Nesamvuni et al., 2000). It has been observed that different models might be 
needed to predict BW in different environmental conditions, body condition and breeds (Enevoldsen and Kristensen, 1997). Little work has been done on use of linear body measurements (LBM) of Jamuna basin sheep and their possible use for estimating BW. Hasan and Talukder (2011) worked a few parameters of native sheep of Bangladesh but not stated on prediction of BW. The present study worked on 14 parameters of Jamuna basin sheep for prediction of body weight. Hence, the study was carried out to estimate the body measurement relationships and to derive prediction equations for live weight using different body measurements of Jamuna basin sheep.

\section{MATERIALSAND METHODS}

\section{Study area and selection of sheep}

The study was conducted at two Upazila like Sherpur Sadar and Nalitabari in Sherpur district from January 2019 to June 2019. A total of 520 individual records of sheep (47 males and 473 females) from 60 households were collected. According to the age, animals were divided into 3 groups: One to nine months (320), 1.3-1.6 years (161) and 1.9-2 years (39). The age category was determined by dentition as outlined by Abegaz and Awgichew (2009). In total, 520 sets of measurements were obtained against 14 variables. BW was taken using a weighing scale, and the linear measurements were taken as described by Abegaz and Awgichew (2009). The measurements were taken using the tailor's tape measure and measuring stick while animals were on standing position as previously used for goats (Khan et al., 2006). Data were collected before grazing in the morning.

\section{Daily routine works of farmers for sheep}

All sheep were kept inside the house at night and grazing 6-7 hours by day. The house was cleaned every morning. Sheep were supplied with pure drinking water ad libitum. Some supplements were fed ( $150 \mathrm{~g} /$ day $)$ in morning. Sheep were bath with shampoo and fresh water weekly basis by using body brush.

\section{Data collection}

The data were collected for all body measurements directly as per Fig. 1 from individual sheep. It was directly measured with gauge tape according to Fig. 1 parameters. Fourteen parameters were collected weekly basis from farmer to farmer's house according to age, sex and dentition. All the research team was involved in collection different body measurement of Jamuna basin sheep at Sherpur district. An introductory visit was made to study area when the aims and objects of study were explained to the most of the respondents. This helped to create a friendly atmosphere between respondents and researchers. The collected data from this experiment were entered in Microsoft Excel worksheet, organized and processed for further analysis. 


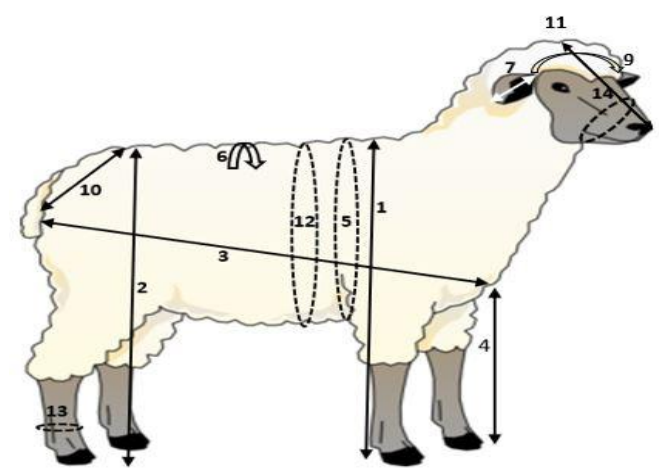

Figure 1. Wither height, 2.Rump height, 3. Body length, 4. Sternum height, 5. Body depth, 6. Bicoastal diameter,7. Ear length, 8.Rump width, 9. Head width,10. Rump length, 11.Head Length,12. Heart girth, 13. Cannon bone circumference,14. Muzzle diameter

\section{Statistical model for live weight}

The following model was adopted for live weight estimation:

Yijklm $=\mu+\mathrm{Si}+\mathrm{Mj}+\mathrm{Rk}+$ Eijk

Where:

Yijklmn: The dependent variable (individual animal record for the trait).

$\mu$ : Overall mean.

Si: Fixed effect of sheep sex ( $i=$ Male, Female).

$\mathrm{Mj}$ : Fixed effect of age according to pair of teeth $\left(j=\right.$ All temporary, $2^{\text {nd }}$ pair permanent, $3^{\text {rd }}$ pair permanent).

Rk: Fixed effect of Location ( $\mathrm{k}=$ Sherpur Sadar, Nalitabari).

Eijk: The residual error.

\section{Statistical analysis}

Data were tabulated and analyzed with descriptive statistical method by fulfilling the objectives of the study. Tabular technique was applied for the analysis of data using descriptive statistical tools like frequency, average and percentages, standard deviation, correlation coefficient and prediction model was developed through SPSSv-20 version computer software. The differences in means were tested using one-way ANOVAs.

\section{RESULTS AND DISCUSSION}

\section{Phenotypic characteristics}

Average BW of combined and individual male and female sheep was $12.28 \pm 2.75$, $14.55 \pm 4.71$ and $12.05 \pm 2.36 \mathrm{~kg}$, respectively. Individual $\mathrm{BW}$ was significantly 
$(\mathrm{p}<0.001)$ higher in male (Table 1$)$. The HG was significantly differed between sexes $(\mathrm{p}<0.05)$. RH was $56.95 \pm 4.68$ and $12.05 \pm 2.36$ in male and female which was significantly differed $(\mathrm{p}<0.001)$. The $\mathrm{WH}, \mathrm{SH}, \mathrm{RD}$, and $\mathrm{CC}$ were significantly differed $(\mathrm{p}<0.001)$ between male and female and the value of all mentioned characters were higher in male. Similar estimates for BW were found in Muzaffarnagari, Pugal, Munjal sheep (Yadav et al., 2011). Higher BW was reported in Sahel sheep breeds and Djallonke sheep of Northern Ghana (Birteeb et al., 2012)

Table 1. Body measurements of Jamuna basin sheep based on sex

\begin{tabular}{|c|c|c|c|c|c|c|}
\hline \multirow{2}{*}{$\begin{array}{l}\text { Body Measurements } \\
\text { traits }\end{array}$} & \multirow[b]{2}{*}{$\mathrm{N}$} & \multirow{2}{*}{$\begin{array}{c}\text { Combined sex } \\
\text { Mean+SD }\end{array}$} & \multicolumn{2}{|c|}{ Individual sex } & \multicolumn{2}{|c|}{$\begin{array}{c}\text { Level of } \\
\text { Significant }\end{array}$} \\
\hline & & & $\begin{array}{l}\text { Male (Mean } \pm \\
\text { SD) }\end{array}$ & $\begin{array}{c}\text { Female (Mean } \pm \\
\text { SD) }\end{array}$ & & \\
\hline Body Weight(kg) & 520 & $12.28 \pm 2.75$ & $14.55 \pm 4.71$ & $12.05 \pm 2.36$ & 0.00 & $* * *$ \\
\hline Wither Height $(\mathrm{cm})$ & 520 & $49.42 \pm 3.78$ & $52.10 \pm 5.37$ & $49.15 \pm 3.48$ & 0.00 & $* * *$ \\
\hline Rump height $(\mathrm{cm})$ & 520 & $54.04 \pm 3.88$ & $56.95 \pm 4.68$ & $53.75 \pm 3.67$ & 0.00 & $* * *$ \\
\hline Body length $(\mathrm{cm})$ & 520 & $49.38 \pm 4.57$ & $50.61 \pm 5.92$ & $49.26 \pm 4.40$ & 0.05 & NS \\
\hline Sternum height $(\mathrm{cm})$ & 520 & $28.06 \pm 3.01$ & $30.31 \pm 4.93$ & $27.84 \pm 2.64$ & 0.00 & $* * *$ \\
\hline Body depth(cm) & 520 & $53.09 \pm 4.40$ & $55.31 \pm 5.68$ & $52.87 \pm 4.20$ & 0.00 & $* * *$ \\
\hline $\begin{array}{l}\text { Bi-coastal } \\
\text { diameter }(\mathrm{cm})\end{array}$ & 520 & $15.07 \pm 2.58$ & $15.0 \pm 2.97$ & $15.07 \pm 2.55$ & 0.84 & NS \\
\hline Ear length $(\mathrm{cm})$ & 520 & $8.66 \pm 3.32$ & $9.74 \pm 2.25$ & $8.55 \pm 3.39$ & 0.01 & $*$ \\
\hline Rump width(cm) & 520 & $15.72 \pm 2.33$ & $15.63 \pm 2.90$ & $15.73 \pm 2.27$ & 0.78 & NS \\
\hline Head width $(\mathrm{cm})$ & 520 & $12.87 \pm 2.20$ & $13.34 \pm 3.10$ & $12.83 \pm 2.09$ & 0.13 & NS \\
\hline Rump length $(\mathrm{cm})$ & 520 & $14.30 \pm 2.29$ & $14.61 \pm 2.74$ & $14.27 \pm 2.24$ & 0.32 & NS \\
\hline Head length $(\mathrm{cm})$ & 520 & $18.23 \pm 2.30$ & $18.63 \pm 3.03$ & $18.19 \pm 2.21$ & 0.21 & NS \\
\hline Heart girth $(\mathrm{cm})$ & 520 & $55.02 \pm 4.71$ & $57.0 \pm 6.32$ & $54.82 \pm 4.48$ & 0.003 & $* *$ \\
\hline $\begin{array}{l}\text { Canon bone } \\
\text { circumference }(\mathrm{cm})\end{array}$ & 520 & $9.20 \pm 1.01$ & $9.78 \pm 1.12$ & $9.15 \pm 0.99$ & 0.00 & $* * *$ \\
\hline Muzzle diameter(cm) & 520 & $16.65 \pm 1.73$ & $17.40 \pm 2.28$ & $16.57 \pm 1.65$ & 0.002 & $* *$ \\
\hline
\end{tabular}

$* * *(\mathrm{p}<0.001), * *(\mathrm{p}<0.01), *(\mathrm{p}<0.05)$, NS- Non significant

irrespective of age and sex. Yadav et al. (2011) characterized Munjal sheep and reported average BW of males and females as 60.05 and $43.95 \mathrm{~kg}$, respectively which is higher than the present findings. The mean BW obtained in this study was lower than the average BW of central highland sheep, Rift Valley sheep and Menz sheep in Amhara Regional State (Tibbo et al., 2004). Many previous studies reported significant effects of environmental factors like sex and age on BW in accordance with the present study (Tadesse and Gebremariam, 2010; Shirzeyli et al., 2013). The higher mean linear body weight (LBW) values observed in male than female might be due to relatively large physical features of male as a result of natural hormonal 
variations (Maria et al., 2003).WH, RH, BL, SH, RD, BD, EL, RW, HW, RL, HL, $\mathrm{HG}, \mathrm{CC}$ and MD were 49.42 $\pm 3.78,54.04 \pm 3.88,49.38 \pm 4.57,28.06 \pm 3.01,53.09 \pm 4.40$,

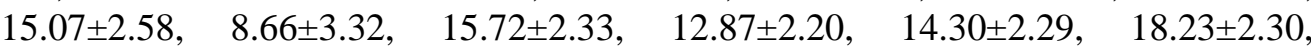
$55.02 \pm 4.71,9.20 \pm 1.01$ and $16.65 \pm 1.73 \mathrm{~cm}$, respectively (Table 1). Jamuna basin sheep had lower HG than Washera, Farta and Gumuz sheep (Abegaz et al., 2011). It had shorter BL than Gumuz sheep (Abegaz et al., 2011). HG continued growing up to old age; indicates that different body parts mature at different ages (Mavule et al., 2013). Gopal and Prasad (2007) stated that the overall least square means for BL, WH and chest girth were 82.9, 83.9 and $85.1 \mathrm{~cm}$ respectively in adult Muzaffarnagari sheep in India, which is much higher than the present findings. The present finding was in close agreement with all body measurements with the reports of Gowaneet al. (2010a) in Malpura sheep and Singh et al. (2014) in Marwari sheep. Mandal et al. (2015) found variable live weight in different sheep breeds, owing to breed differences, which are genetic in nature.

\section{Body measurement according to age}

From the mean BW, BD, HL and HG (Table 2) of Jamuna basin sheep was found to increase significantly with age $(\mathrm{p}<0.001)$. The mean $\mathrm{WH}, \mathrm{RH}$ and MD of sheep with age was also seen to be increasing at1-9 month and 1.3-1.6 years age groups which were significantly differed $(\mathrm{p}<0.001)$. The mean BL, RW and HW of sheep were also seen to be increasing in 1.3-1.6 years than 1-9-month age groups. The mean EL, RL and CC of sheep with age were seen almost similar in all groups. The mean of SH of sheep was found higher in 1.9-2 years age group than that of all 1-9 month and 1.31.6 years age group but not significant. BW, WH, RH, BL, RD, RW, HL, HG and MD were significant $(p<0.001)$ among different ages. RL was significant $(p<0.01)$ among different ages. The BW of sheep (1.9-2 years) was $14.55 \pm 3.43 \mathrm{~kg}$ showing this population to be of lower BW. Age group also affected BW of sheep. Yearlings had a lower weight than other higher age groups, and this might be because of the fact that yearlings have not yet achieved mature BW. A significant effect of sex and age of sheep on BW is reported by Mavule et al. (2013) for different breeds of sheep. Both BW and HG showed an increase at the age group which might be responsible for maturation. 
Table 2. Body measurements of Jamuna basin sheep according to age

\begin{tabular}{|c|c|c|c|c|c|}
\hline \multirow[b]{2}{*}{ Body Measurements traits } & \multicolumn{3}{|c|}{ Age groups } & \multicolumn{2}{|c|}{$\begin{array}{c}\text { Level of } \\
\text { significant }\end{array}$} \\
\hline & $\begin{array}{l}1-9 \text { month } \\
(\mathrm{ME} \pm \mathrm{SD})\end{array}$ & $\begin{array}{c}\text { 1.3-1.6 years } \\
(\mathrm{ME} \pm \mathrm{SD})\end{array}$ & $\begin{array}{c}1.9-2 \text { years } \\
(\mathrm{ME} \pm \mathrm{SD})\end{array}$ & & \\
\hline Body Weight(kg) & $11.49 \pm 2.44$ & $13.3 \pm 2.5$ & $14.55 \pm 3.43$ & 0.00 & $* * *$ \\
\hline Wither Height $(\mathrm{cm})$ & $48.72 \pm 3.77$ & $50.59 \pm 3.33$ & $50.35 \pm 4.31$ & 0.00 & $* * *$ \\
\hline Rump height(cm) & $53.26 \pm 3.84$ & $55.15 \pm 3.59$ & $55.76 \pm 3.78$ & 0.00 & $* * *$ \\
\hline Body length $(\mathrm{cm})$ & $48.38 \pm 4.33$ & $51.19 \pm 4.38$ & $50.12 \pm 4.88$ & 0.00 & $* * *$ \\
\hline Sternum height $(\mathrm{cm})$ & $28.09 \pm 3.14$ & $27.96 \pm 2.45$ & $28.20 \pm 3.87$ & 0.86 & NS \\
\hline Body depth(cm) & $51.94 \pm 4.36$ & $54.72 \pm 3.86$ & $55.84 \pm 3.49$ & 0.00 & $* * *$ \\
\hline Bi-coastal diameter $(\mathrm{cm})$ & $14.90 \pm 2.66$ & $15.40 \pm 2.45$ & $15.07 \pm 2.38$ & 0.12 & NS \\
\hline Ear length $(\mathrm{cm})$ & $8.67 \pm 3.23$ & $8.67 \pm 3.23$ & $7.84 \pm 4.15$ & 0.23 & NS \\
\hline Rump width(cm) & $15.42 \pm 2.41$ & $15.42 \pm 2.41$ & $15.76 \pm 2.13$ & 0.00 & $* * *$ \\
\hline Head width $(\mathrm{cm})$ & $12.79 \pm 2.23$ & $12.79 \pm 2.23$ & $12.43 \pm 2.02$ & 0.10 & NS \\
\hline Rump length(cm) & $14.05 \pm 2.35$ & $14.05 \pm 2.35$ & $14.35 \pm 1.72$ & 0.005 & $* *$ \\
\hline Head length $(\mathrm{cm})$ & $17.79 \pm 2.44$ & $17.79 \pm 2.44$ & $19.05 \pm 1.77$ & 0.00 & $* * *$ \\
\hline Heart girth $(\mathrm{cm})$ & $53.67 \pm 4.23$ & $53.67 \pm 4.23$ & $58.43 \pm 5.01$ & 0.00 & $* * *$ \\
\hline $\begin{array}{l}\text { Canon bone } \\
\text { circumference }(\mathrm{cm})\end{array}$ & $9.15 \pm 1.09$ & $9.15 \pm 1.09$ & $9.41 \pm .88$ & 0.18 & NS \\
\hline Muzzle diameter $(\mathrm{cm})$ & $16.33 \pm 1.76$ & $16.33 \pm 1.76$ & $17.07 \pm 2.00$ & 0.00 & $* * *$ \\
\hline
\end{tabular}

\section{Correlation coefficient between body weight and body measurements}

In all 1-9-month age group, 12 out of 14 variables were significantly correlated with BW (Table 3). This means that those sheep of 1-9-month age group had relatively high $\mathrm{HG}, \mathrm{r}=0.76, p<0.01$, were likely to have high $\mathrm{BW}$. BW was also positive correlated with RD $(\mathrm{r}=0.69, p<0.01)$, WH $(\mathrm{r}=0.60, p<0.01)$, RH $(\mathrm{r}=0.54$, $p<0.01)$, BL $(\mathrm{r}=0.43, p<0.01), \mathrm{SH}(\mathrm{r}=0.38, p<0.01), \mathrm{MD}(\mathrm{r}=0.29, p<0.01), \mathrm{CC}(\mathrm{r}$ $=0.28, p<0.01)$, HL $(\mathrm{r}=0.21, p<0.01), \mathrm{RW}(\mathrm{r}=0.15, p<0.05)$, RL $(\mathrm{r}=0.14$, $p<0.05)$, EL ( $\mathrm{r}=0.13, p<0.05)$ where HG, RD, WH, RH, BL, SH, MD, CC, HL was strongly significant $(\mathrm{p}<0.01)$ and $\mathrm{RL}$, EL was significant $(\mathrm{p}<0.05)$.

In 1.9-2 years age group, 10 out of 14 variables were significantly $(p<0.01)$ correlated with BW. This means that those sheep at1.9-2 years age group had relatively high $\mathrm{HG}, \mathrm{r}=0.70, p<0.01$, were likely to have high $\mathrm{BW}$. $\mathrm{BW}$ was also positively correlated with $\mathrm{WH}(\mathrm{r}=0.57, p<0.01), \mathrm{RD}(\mathrm{r}=0.55, p<0.01), \mathrm{RH}(\mathrm{r}=$ $0.50, p<0.01), \mathrm{BL}(\mathrm{r}=0.47, p<0.01), \mathrm{SH}(\mathrm{r}=0.32, p<0.01), \mathrm{CC}(\mathrm{r}=0.26, p<0.01)$, $\mathrm{RW}(\mathrm{r}=0.26, p<0.01), \mathrm{MD}(\mathrm{r}=0.21, p<0.001)$, HL $(\mathrm{r}=0.16, p<0.05)$ where HG, $\mathrm{WH}, \mathrm{RD}, \mathrm{RH}, \mathrm{BL}, \mathrm{SH}, \mathrm{CBC}, \mathrm{RW}, \mathrm{MD}$, was strongly significant $(\mathrm{p}<0.01)$ and $\mathrm{HL}$ was significant $(p<0.05)$.In 1.9-2 years age group, 6 out of the 14 variables were 
significant $(p<0.01)$ correlated with $\mathrm{BW}$. This means that those sheep at 1.9-2 years age group had relatively high $\mathrm{RH}, \mathrm{r}=0.68, p<0.01$, were likely to have high BW. BW was also positively correlated with $\mathrm{BL}(\mathrm{r}=0.67, p<0.01), \mathrm{WH}(\mathrm{r}=0.62$, $p<0.001), \mathrm{BD}(\mathrm{r}=0.61, p<0.01), \mathrm{HG}(\mathrm{r}=0.60, p<0.01), \mathrm{SH}(\mathrm{r}=0.49, p<0.01)$ where $\mathrm{RH}, \mathrm{BL}, \mathrm{WH}, \mathrm{RD}, \mathrm{HG}, \mathrm{SH}$ were strongly significant $(\mathrm{p}<0.01)$. According to multiple regression analysis it was found that the best estimation age was 1.9-2 years and then 1-9 month and 1.3-1.6 years, respectively (Table 4).

The correlation is one of the most common and useful statistics that describes the degree of relationship between two variables. There was a positive and significant correlation between weight and other body measurements except with BD and HW (Table 3). The highest correlation coefficient obtained was between BW and HG $(\mathrm{r}=$ $0.76)$ which was followed by weight with RD $(r=0.68)$. The higher correlation of LBW with BW indicates that these LBW can be used as indirect selection criteria in the absence of weighing scale (Khan et al., 2006). The observed positive $(p<0.05)$ correlations between weight and other body measurements was in agreement with literature of Melesse et al. (2013). In general, it was seen that body measurements such as BL and chest girth had a high relationship with BW of sheep. Correlation coefficients may be affected by age, sex, season, feeding condition. So, it is not expected to achieve same results in different breeds and environments, and the effectiveness of body measurements in BW prediction could be changed (Cam et al., 2010). High positive phenotypic correlation coefficients were observed between live weight and body measurements of animals in different age groups (2-6 years) (Yilmaz et al., 2013). Fakhraei et al. (2008) reported correlation more than 0.95 between BW with chest girth, BL and height in Iranian Farahani sheep. In another Iranian sheep, Moghania noticeable relationship among body measurements was declared by Hoseini et al. (2010). Lavvaf et al. (2012) presented some reports on such correlations, while there is no accordance with our results. High correlation among body measurement was not supported in two of their investigated breeds. The relationship between BW and body measurements in Saanen goats was investigated by Pesmen and Yardimci (2008). Live weight was found to be highly correlated with HG and BL in their study. The positive correlation coefficient of BW seen in this study with most body measurements demonstrated that BW could be predicted more accurately based on the dimension of various body measurements. Similar results of this study, live weight was found to be highly correlated with body dimensional traits in sheep (Lavvaf et al., 2012). Correlation values were seen positive and significant in major studied parameters (WH, BL and $\mathrm{HG}$ ) which were similar to the results of Cam et al.(2010). Results obtained from all temporary age group are in line with Cam et al. (2010) as they have reported high phenotypic correlation between HG and BW that strongly entails the importance of relationship between $\mathrm{HG}$ and $\mathrm{BW}$. WH is positively significantly and strongly correlated to BW of both sexes and all age groups of breed. Most of the studied animals, girth circumferences are positively, strongly and significantly correlated to $\mathrm{BW}$. The $\mathrm{BW}$ comes nearer of body 
measurement estimation when sheep grow under same breed, age, sex, feeding, deworming, management condition etc. The accurate prediction of BW may be considered as a framework for record keeping in rural areas. The economic value of sheep distributed to a special geographical location may be estimated better.

Table 3. Correlation coefficient between body weight and body measurements in Jamuna basin sheep

\begin{tabular}{lccc}
\hline \multirow{2}{*}{ Body Measurements traits } & \multicolumn{3}{c}{ Age groups } \\
\cline { 2 - 4 } & $\begin{array}{c}1-9 \text { month } \\
(\mathrm{ME} \pm \mathrm{SD})\end{array}$ & $\begin{array}{c}1.3-1.6 \text { years } \\
(\mathrm{ME} \pm \mathrm{SD})\end{array}$ & $\begin{array}{c}1.9-2 \text { years } \\
(\mathrm{ME} \pm \mathrm{SD})\end{array}$ \\
\hline Wither Height $(\mathrm{cm})$ & $0.604^{* *}$ & $0.569^{* *}$ & $0.622^{* *}$ \\
Rump height $(\mathrm{cm})$ & $0.537^{* *}$ & $0.497^{* *}$ & $0.679^{* *}$ \\
Body length $(\mathrm{cm})$ & $0.428^{* *}$ & $0.466^{* *}$ & $0.669^{* *}$ \\
Sternum height $(\mathrm{cm})$ & $0.381^{* *}$ & $0.322^{* *}$ & $0.487^{* *}$ \\
Body depth $(\mathrm{cm})$ & $0.691^{* *}$ & $0.548^{* *}$ & $0.614^{* *}$ \\
Bi-coastal diameter$(\mathrm{cm})$ & 0.023 & 0.026 & 0.015 \\
Ear length $(\mathrm{cm})$ & $0.131^{*}$ & 0.07 & 0.282 \\
Rump width $(\mathrm{cm})$ & $0.147^{* *}$ & $0.259^{* *}$ & 0.167 \\
Head width $(\mathrm{cm})$ & 0.036 & 0.084 & -0.135 \\
Rump length $(\mathrm{cm})$ & $0.142^{*}$ & 0.088 & 0.035 \\
Head length $(\mathrm{cm})$ & $0.205^{* *}$ & $0.160^{*}$ & -0.055 \\
Heart girth $(\mathrm{cm})$ & $0.756^{* *}$ & $0.704^{* *}$ & $0.607 * *$ \\
Canon bone & & & 0.258 \\
circumference(cm) & $0.278^{* *}$ & $0.263^{* *}$ & -0.001 \\
Muzzle diameter(cm) & $0.289^{* *}$ & $0.211^{* *}$ & \\
\hline
\end{tabular}

$* *(\mathrm{p}<0.01), *(\mathrm{p}<0.05)$

\section{Stepwise multiple regression based on age}

In 1-9 month age group, the equation (Table 4);

$\mathrm{BW}=-15.53+0.24 \mathrm{HG}+0.13 \mathrm{WH}+0.16 \mathrm{BD}-.1 \mathrm{RW}+0.05 \mathrm{EL}$, was found to be the best fitted equation because, it has highest $\mathrm{R}^{2}$ of $64 \%$ and highest adj. $\mathrm{R}^{2}$ of 0.63 , this indicates that $63 \%$ of variance in BW was explained by the model. LBW was significant $(\mathrm{p}<0.001)$.

In 1.3-1.6 years age group, the equation;

$\mathrm{BW}=-15.65+0.31 \mathrm{HG}+0.22 \mathrm{WH}$, was found to be the best fitted equation because, it has highest $\mathrm{R}^{2}$ value of $56 \%$ and highest adj. $\mathrm{R}^{2}$ of 0.55 , this indicates that $55 \%$ of variance in BW was explained by the model. LBW was significant $(\mathrm{p}<0.001)$. 
In 1.9-2 years age group, the equation;

$\mathrm{BW}=-24.51+0.21 \mathrm{RH}+0.35 \mathrm{HG}+0.19 \mathrm{BL}-0.78 \mathrm{RL}+1.2 \mathrm{RW}-0.87 \mathrm{HW}$, was found to be the best fitted equation because, it has higher $\mathrm{R}^{2}$ value of $83 \%$ and the highest adj. $\mathrm{R}^{2}$ of 0.80 , this indicates that $80 \%$ of variance in BW was explained by the model. LBW was significant $(p<0.001)$ (Table 5$). R^{2}$ and adj. $R^{2}$ can be considered as criteria important in selection of appropriate linear model. The equations with larger $\mathrm{R}^{2}$ and adj. $R^{2}$ showed a range similar to the range observed in actual weight category. Among multiple regression models of Yilmaz et al. (2013), highest coefficients of determination were obtained from the models formed at BL and chest girth together in Karya sheep $\left(\mathrm{R}^{2}=0.79, \mathrm{R}^{2}=0.87\right)$. In the literature, the most appropriate parameters to predict the BW in the established regression equations were HG and BL. When both HG and BL were considered in equations simultaneously, the highest estimation precisions were gained in goat (Tadesse et al., 2012). The greatest variation of BW was accounted by combination of $\mathrm{WH}$, chest girth and BL than individually of all age groups in both sexes (Thiruvenkadan, 2005). The result was generally in agreement with literature of Thiruvenkadan (2005) that HG was the best predictor of weight. Multiple regression models estimated weight with better accuracy of prediction increased with the increased number of variables (Melesse et al., 2013).

Table 4. Stepwise multiple regression based on age

\begin{tabular}{|c|c|c|c|c|c|}
\hline $\begin{array}{l}\text { Age } \\
\text { Group }\end{array}$ & $\mathrm{N}$ & Model & $\begin{array}{c}\mathrm{R} \\
\text { square }\end{array}$ & $\begin{array}{l}\text { Adjusted } \\
\text { R Square }\end{array}$ & Sig. \\
\hline \multirow{4}{*}{$\begin{array}{l}1-9 \\
\text { month }\end{array}$} & \multirow{4}{*}{320} & $-15.43+0.35 \mathrm{HG}+0.16 \mathrm{WH}$ & 0.61 & 0.61 & 0.000 \\
\hline & & $-15.95+.27 \mathrm{HG}+0.13 \mathrm{WH}+0.11 \mathrm{BD}$ & 0.63 & 0.62 & 0.000 \\
\hline & & $\begin{array}{l}-15.37+0.25 \mathrm{HG}+0.14 \mathrm{WH}+0.15 \mathrm{BD}- \\
0.1 \mathrm{RW}\end{array}$ & 0.63 & 0.63 & 0.000 \\
\hline & & $\begin{array}{l}-15.53+0.24 \mathrm{HG}+0.13 \mathrm{WH}+0.16 \mathrm{BD}- \\
.1 \mathrm{RW}+0.05 \mathrm{EL}\end{array}$ & 0.64 & 0.63 & 0.000 \\
\hline \multirow{3}{*}{$\begin{array}{l}1.3-1.6 \\
\text { years }\end{array}$} & \multirow{3}{*}{161} & $-8.86+0.39 \mathrm{HG}$ & 0.49 & 0.49 & 0.000 \\
\hline & & $-15.65+0.31 \mathrm{HG}+0.22 \mathrm{WH}$ & 0.56 & 0.55 & 0.000 \\
\hline & & $-19.79+0.61 \mathrm{RH}$ & 0.46 & 0.44 & 0.000 \\
\hline \multirow{5}{*}{$\begin{array}{l}1.9-2 \\
\text { years }\end{array}$} & \multirow{5}{*}{39} & $-28.97+0.48 \mathrm{RH}+0.48 \mathrm{HG}$ & 0.61 & 0.59 & 0.000 \\
\hline & & $-28.90+0.32 \mathrm{RH}+0.24 \mathrm{HG}+0.21 \mathrm{BL}$ & 0.66 & 0.64 & 0.000 \\
\hline & & $\begin{array}{l}-23.88+0.24 \mathrm{RH}+0.28 \mathrm{HG}+0.31 \mathrm{BL}- \\
0.54 \mathrm{RL}\end{array}$ & 0.72 & 0.69 & 0.000 \\
\hline & & $\begin{array}{l}-27.19+0.23 \mathrm{RH}+0.35 \mathrm{HG}+0.26 \mathrm{BL}- \\
0.92 \mathrm{RL}+0.50 \mathrm{RW}\end{array}$ & 0.77 & 0.74 & 0.000 \\
\hline & & $\begin{array}{l}-24.51+0.21 \mathrm{RH}+0.35 \mathrm{HG}+0.19 \mathrm{BL}- \\
0.78 \mathrm{RL}+1.2 \mathrm{RW}-0.87 \mathrm{HW}\end{array}$ & 0.83 & 0.80 & 0.000 \\
\hline
\end{tabular}




\section{Stepwise multiple regression based on sex}

In male group, the equation (Table 5);

$\mathrm{BW}=-28.91+0.43 \mathrm{HG}+0.35 \mathrm{WH}$, was found to be the best fitted equation because, it has highest $\mathrm{R}^{2}$ of $88 \%$ and highest Adj. $\mathrm{R}^{2}$ of 0.88 , this indicates that $88 \%$ of variance in BW was explained by the model. LBW were significant $(\mathrm{p}<0.001)$.

In female group, the equation;

$\mathrm{BW}=-10.62+0.27 \mathrm{HG}+0.13 \mathrm{WH}+0.06 \mathrm{BD}-0.13 \mathrm{HW}+0.07 \mathrm{BL}-0.10 \mathrm{SH}-0.10 \mathrm{RL}$, was found to be the best fitted equation because, it was highest $\mathrm{R}^{2}$ value of $59 \%$ and highest adj. $\mathrm{R}^{2}$ of 0.58 , this indicates that $58 \%$ of variance in $\mathrm{BW}$ was explained by the model.LBW were significant $(\mathrm{p}<0.001)$ (Table 5).An increase in the coefficient of determination was observed as more variables were included in the prediction equations which indicates more precision in the determination of BW based on these LBM (Tadesse and Gebremariam, 2010). Similarly, findings reported by Tadesse and Gebremariam (2010) on high land sheep in Tigray Region, North-Ethiopia, indicated that incorporating more LBM in the prediction equation has improved prediction accuracy. This means that considering more parameters of LBM especially after applying principle of Parsimony or Occams razor (which stated that a model with fewer variables ( $p$ ) was preferred to the one with many variables) (Yakubu and Musa, 2013) as it was applied in this study, could provide better precision in predicting the BW using established equations under each age category.

Table 5. Stepwise multiple regression based on sex

\begin{tabular}{|c|c|c|c|c|c|}
\hline Sex & $\mathrm{N}$ & Model & $\mathrm{R}$ square & $\begin{array}{l}\text { Adjusted R } \\
\text { Square }\end{array}$ & Sig. \\
\hline \multirow{6}{*}{ Male } & \multirow{6}{*}{47} & $-23.93+0.67 \mathrm{HG}$ & 0.82 & 0.81 & 0.000 \\
\hline & & $-28.91+0.43 \mathrm{HG}+0.35 \mathrm{WH}$ & 0.88 & 0.88 & 0.000 \\
\hline & & $-8.98+0.38 \mathrm{HG}$ & 0.53 & 0.52 & 0.000 \\
\hline & & $-13.46+0.28 \mathrm{HG}+0.12 \mathrm{WH}+0.07 \mathrm{BD}$ & 0.56 & 0.55 & 0.000 \\
\hline & & $\begin{array}{l}-12.48+0.27 \mathrm{HG}+0.11 \mathrm{WH}+0.09 \mathrm{BD}- \\
0.08 \mathrm{HW}\end{array}$ & 0.56 & 0.56 & 0.000 \\
\hline & & $\begin{array}{l}-12.48+0.27 \mathrm{HG}+0.11 \mathrm{WH}+0.09 \mathrm{BD}- \\
0.08 \mathrm{HW}\end{array}$ & 0.57 & 0.57 & 0.000 \\
\hline \multirow[t]{3}{*}{ Female } & \multirow[t]{3}{*}{473} & $\begin{array}{l}-12.51+0.26 \mathrm{HG}+0.09 \mathrm{WH}+0.07 \mathrm{BD}- \\
0.12 \mathrm{HW}+0.06 \mathrm{BL}\end{array}$ & 0.58 & 0.57 & 0.000 \\
\hline & & $\begin{array}{l}-11.45+0.26 \mathrm{HG}+0.12 \mathrm{WH}+0.07 \mathrm{BD}- \\
0.14 \mathrm{HW}+0.06 \mathrm{BL}-0.06 \mathrm{SH}\end{array}$ & 0.58 & 0.58 & 0.000 \\
\hline & & $\begin{array}{l}-10.62+0.27 \mathrm{HG}+0.13 \mathrm{WH}+0.06 \mathrm{BD}- \\
0.13 \mathrm{HW}+0.07 \mathrm{BL}-0.10 \mathrm{SH}-0.10 \mathrm{RL}\end{array}$ & 0.59 & 0.58 & 0.000 \\
\hline
\end{tabular}




\section{CONCLUSIONS}

It is revealed that live weight of Jamuna basin sheep can be estimated with more accuracy using different body measurements and stepwise multiple regression. Extra costs and waste time can be saved by this method. Stepwise multiple regression analysis according to age in all 1-9 month groups showed that the body weight was found the best fitted equation having the highest $\mathrm{R}^{2}$ value $64 \%(\mathrm{BW}=-$ $15.53+0.24 \mathrm{HG}+0.13 \mathrm{WH}+0.16 \mathrm{BD}-.1 \mathrm{RW}+0.05 \mathrm{EL}$ ) whereas in 1.3-1.6 and 1.9-2 years age group the $\mathrm{R}^{2}$ value for body weight was $56(\mathrm{BW}=-15.65+0.31 \mathrm{HG}+0.22 \mathrm{WH})$ and $83 \%(\mathrm{BW}=-24.51+0.21 \mathrm{RH}+0.35 \mathrm{HG}+0.19 \mathrm{BL}-0.78 \mathrm{RL}+1.2 \mathrm{RW}-0.87 \mathrm{HW})$, respectively. $\mathrm{R}^{2}$ value for body weight in male $(\mathrm{BW}=-28.91+0.43 \mathrm{HG}+0.35 \mathrm{WH})$ and female (BW $=-10.62+0.27 \mathrm{HG}+0.13 \mathrm{WH}+0.06 \mathrm{BD}-0.13 \mathrm{HW}+0.07 \mathrm{BL}-0.10 \mathrm{SH}-$ $0.10 \mathrm{RL}$ ) was 88 and $59 \%$, respectively. So, it is recommended that the best prediction parameters of body weight were $\mathrm{HG}, \mathrm{WH}, \mathrm{BD}, \mathrm{RW}, \mathrm{EL}, \mathrm{RH}, \mathrm{BL}$ and HW.

\section{ACKNOWLEDGEMENTS}

The authors are highly grateful to the Krishi Gobeshona Foundation (KGF) for funding this research project.

\section{REFERENCES}

Abegaz, S. and Awgichew, K. (2009). Technical Bulletin No.23: Estimation of weight and age of sheep and goats, (Tami A, Gipson TA, Merkel RC. Edn.). Ethiopia Sheep and goat productivity Improvement program (ESGPIP), Ethiopia, Pp. 3-9.

Abegzal, S., Hedge, B.P. and Taye, M. (2011). Growth and physical body characteristics of Gurmuz sheep under Traditional management systems in Amhara Regional state, Ethiopia. Livestock Research for Rural Development, 23(5). http://www.lrrd.org/ $\operatorname{lrd} 23 / 5 /$ abeg23117.

Bhuiyan, A.K.F.H. (2006). Livestock genetic resources in Bangladesh. Preservation and Management International conference on livestock services. Chinese Academy of Agricultural Sciences (CAAS). Beijing, China.

Birteeb, P.T., Peters, S.O., Yakubu, A., Adeleke, M.A. and Ozoje, M.O. (2012). Multivariate characterization of the phenotypic traits of Djallonke and Sahel sheep in Northern Ghana. Tropical Animal Health Production, 45:267-74.

Cam, M.A., Olfaz, M. and Soydan, E. (2010). Possibilities of using morphometrics characteristics as a tool for body weight prediction in Turkish hair goats (kilkeci). Asian Journal of Animal Veterinary Advance, 5: 52-59.

DLS. (2019). Livestock economy report. Department of Livestock Services, Bangladesh.

Fakhraei, J. Rahimi, H. and Mansuri, H. (2008). Using somebody measurements for estimating body weight in Farahani sheep. Journal of Research and Knowledge in Animal Science, 2:31-39.

Gowane, G.R., Chopra, A., Prakash, V. and Arora, A.L. (2010a). Estimates of (co)variance components and genetic parameters for body weights and first greasy fleece weight in Malpura sheep. Livestock Science, 131:94-101. 
Gopal, D. and Prasad, H. (2007). Morphological characteristics, live weight and management practices of Muzaffarnagari sheep in the home tract. The Indian Journal of Small Ruminants, 13:27-30.

Hoseini, V.M. Miraei, Ashtiani, R. Pakdel, A. and Moradi, H. (2010). Evaluation the accuracy of body linear measurements in Moghani lambs to predict carcass production and carcass fat content after slaughter. The $4^{\text {th }}$ Iranian Congress on Animal Science, Karaj, Iran.

Hasan, M.R. and Talukder, M.A.I. (2011). Comparative performance of different regional native sheep in Bangladesh. The Bangladesh Veterinarian, 28(2):85-94.

Khan, H. Muhammad, F. Ahmad, R. Nawaz, G. Rahimullah and Zubair, M. (2006). Relationship of body weight with linear body measurements in goat. Journal of Agricultural and Biological Science, 1(3): 51-54

Lavvaf, A., Noshari, A. and Farahvash, T. (2012). Evaluation of the relationship between body measurements and carcass traits of finishing Afshari and Zandi rams. Asian Journal of Animal and Veterinary Advances, 7:187-192.

Moaeen-ud-Din, Ahmad, M.N. Iqbal, A. and Abdullah, M. (2006). Evaluation of different formulas for weight estimation in Beetal, Teddi and Crossbred (Beetal x Teddy) goats. Journal of Animal and Plant Science, 16(3-4): 70-74.

Maria, S.F., Castelli, L., Bogani, D. and Panella, F. (2003). The measurement of chest girth as an alternative to weight determination in the performance recording of meat sheep. Italian Journal of Animal Science, 2:123-129.

Movule, B. S., Muchenje, V., Benzuidenhout, C. C. and Kunene, N. W. (2013). Morphological structure of Zulu sheep based on principle component analysis of body measurements. Small Ruminant Research, 111(1-3):23-30.

Melesse, A.S., Banerjee, A., Lakew, F., Mersha, F., Hailemariam, S. Tsegaye, A. and Makebo, T. (2013). Morphological characterization of indigenous sheep in Southern Regional State, Ethiopia. Animal Generation Resources, 52:39-50.

Mandal, A., Karunakaran, M., Sharma, D.K., Baneh, H. and Rout, P.K. (2015). Variance components and genetic parameters of growth traits and Kleiber ratio in Muzaffarnagari sheep. Small Ruminant Research, 132:79-85.

Nesamvuni, A.E., Mulaudzi, J., Ramanyimi, N.D. and Taylor, G.J. (2000). Estimation of body weight in Nguni type cattle under communal management conditions. South African Journal of Animal Science, 30 (1):97-98.

Nsoso, S.J., Podisi, B., Ostogile, E. Mokhutshwane, B.S. and Ahmadu, B. (2004). Phenotypic characterization of indigenous Tswana goats and sheep breeds in Botswana: continuous traits. Tropical Animal Health and Production, 36:789-800.

Pesmen, G. and Yardimci M. (2008). Estimating the live weight using some body measurements in Saanen goat. Archivos de Zootecnia, 11: 30-40.

Riva, J. Rizzi, R. Marelli, S. and Cavalchini, L.G. (2004). Body measurements in Bergamasca sheep. Small Ruminant Research, 55:221-227.

Sultana, N., Hasan, N., Ershaduzzaman, M., Talukder, M.A.I. andIqbal, A. (2011). Effects of intensive and semi-intensive feeding system on productive and reproductive performances of native sheep. Journal of Scientific Research, 3(3):693-698. 
Slippers, S.C., Letty, B.A. and De-Vilter J.R. (2000). Production of the body weight of Nguni goats. South African Journal of Animal Science, 30:127-128.

Singh, H., Pannu, U., Narula, H.K., Chopra, A., Naharwara, V. and Bhakar, S.K. (2014). Estimates of (co)variance components and genetic parameters of growth traits in Marwari sheep. Journal of Applied Animal Research, 44 (1):27-35.

Shirzeyli, S.H., Lavvaf, A. and Asad, I.A. (2013). Estimation of body weight from body measurements in four breeds of Iranian sheep. Songklanakarin Journal of Science and Technology, 35: 507-511.

Tadesse, A. Tikabo, G. and Gangwar, S.K. (2012). Application of linear body measurements for predicting body weight of Abergelle goat breed in Tigray region, NorthernEthiopia, Global Journal of Bio-science and Biotechnology, 1 (2): 314-319.

Tadesse, A., and Gebremariam, T. (2010). Application of linear body measurements for live body weight estimation of highland sheep in Tigray region, North-Ethiopia. Journal of the Drylands, 3:203-207.

Thiruvenkadan, A.K. (2005). Determination of best fitted regression model for estimation of body weight in Kanniadu kids under farmer's management system. Livestock Research for Rural Development, 17: 103-107.

Tibbo, M., Ayalew, W, Awgichew, K., Ermias, E. and Rege, J.E.O. (2004). On-station characterisation of indigenous Menz and Horro sheep breeds in the central highlands of Ethiopia. FAO/UNEP Animal Genetic Resources Information.

Yadav, D., Arora, R., Bhatia, S. and Singh, G. (2011). Morphological characterization, production and reproduction status of Munjal-A threatened sheep population of NorthWest India. Indian Journal of Animal Sciences, 81:943-945.

Yakubu, A. and Musa-Azara, I.S. (2013). Evaluation of three mathematical functions to describe the relationship between body weight, body condition and testicular dimensions in Yankasa sheep. International Journal of Morphology, 31:1376-1382.

Yilmaz, O. Cemal, I. and Karaca, O. (2013). Estimation of mature live weight using some body measurements in Karya sheep. Tropical Animal Health Production, 45:397- 403. 